Computational Physics and Engineering Division

\title{
K-INFINITE TRENDS WITH BURNUP, ENRICHMENT, AND COOLING TIME FOR BWR FUEL ASSEMBLIES
}

\author{
B. L. Broadhead
}

August 1998

Prepared by the

OAK RIDGE NATIONAL LABORATORY

managed by

LOCKHEED MARTIN ENERGY RESEARCH CORP.

for the

U.S. DEPARTMENT OF ENERGY

under contract DE-AC05-96OR22464 



\section{CONTENTS}

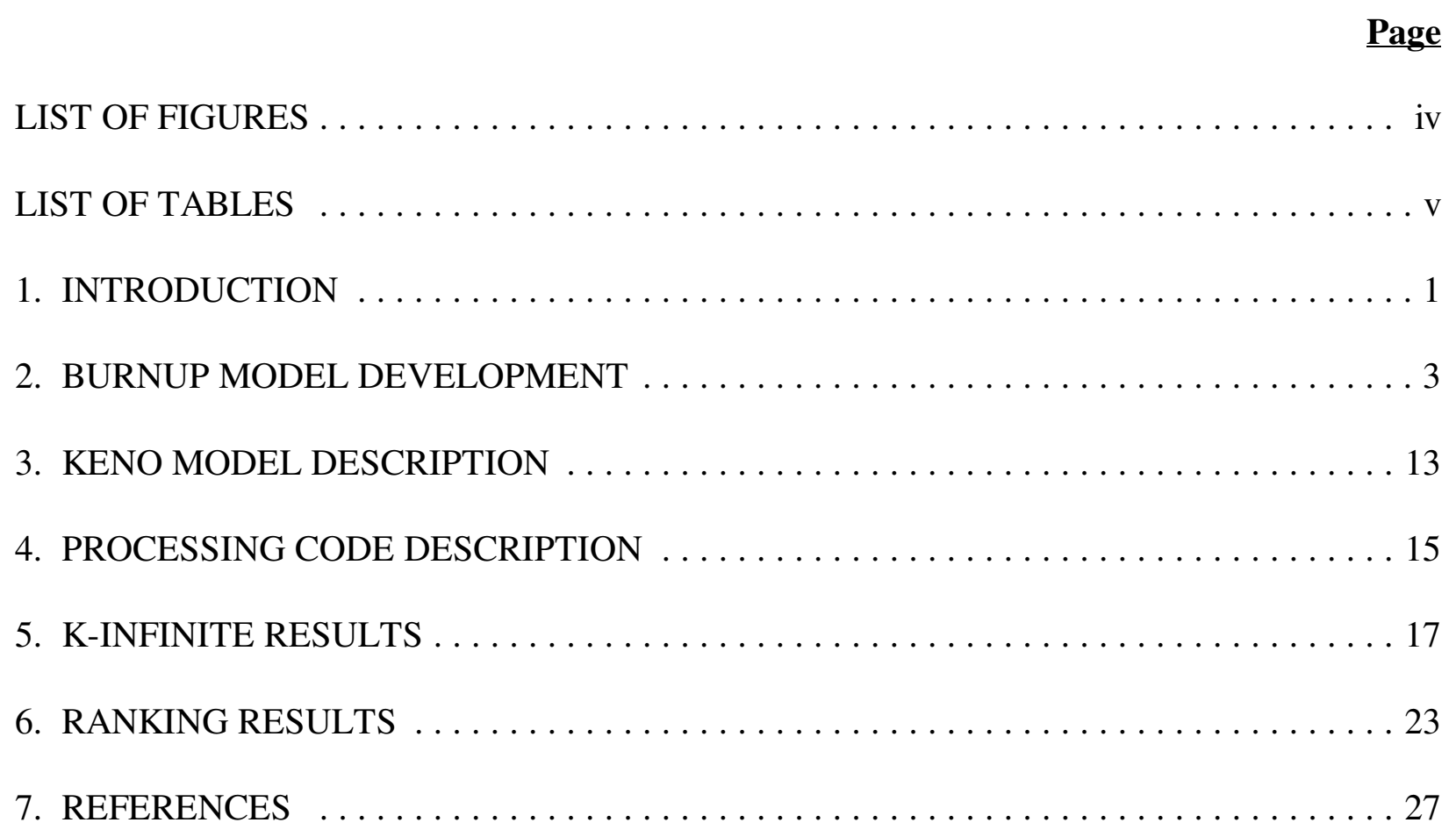




\section{LIST OF FIGURES}

\section{Figure}

Page

1. EIA enrichment-vs-burnup data, each point represents at least 100 assemblies. . . . . . . 2

2. Axial description of BWR assembly used in this work. $\ldots \ldots \ldots \ldots \ldots \ldots$

3. $\quad$ BWR burnup profile used in this study $\ldots \ldots \ldots \ldots \ldots \ldots \ldots \ldots \ldots$

4. Water density and void fractions as a function of node number $\ldots \ldots \ldots \ldots$

5. Plot showing BWR assembly geometry $\ldots \ldots \ldots \ldots \ldots \ldots \ldots \ldots$

6. $\quad$ BWR $\mathrm{k}_{\text {inf }}$ vs burnup/enrichment and cooling time;

average enrichment excludes reflectors . . . . . . . . . . . . . . . . . . . . . 19

7. $\quad$ BWR $\mathrm{k}_{\text {inf }}$ vs burnup/enrichment and cooling time;

average enrichment over entire assembly. . . . . . . . . . . . . . . . . 20

8. Influence of initial enrichment on final $\mathrm{k}_{\mathrm{inf}}$. Low and high enrichments differ from average by $0.2 \mathrm{wt} \%$. . . . . . . . . . . . . . . 21

9. $\quad$ Effect of Gd-rod removal from final $\mathrm{k}_{\mathrm{inf}}$ calculation. $\ldots \ldots \ldots \ldots \ldots \ldots \ldots \ldots$ 


\section{LIST OF TABLES}

\section{$\underline{\text { Table }}$}

Page

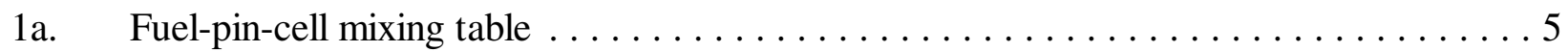

1b. $\quad$ Larger-unit-cell mixing table for lattice type $\mathrm{A} \ldots \ldots \ldots \ldots \ldots \ldots$

1c. $\quad$ Larger-unit-cell mixing table for lattice types $\mathrm{B}, \mathrm{C} \ldots \ldots \ldots \ldots$

1d. Larger-unit-cell mixing table for lattice types $\mathrm{D}, \mathrm{E} \ldots \ldots \ldots \ldots \ldots$

2. Depletion model parameters for $33-G W d / t$ burnup, $3.21 \mathrm{wt} \%$ cases $\ldots \ldots \ldots$. . . 8

3. Depletion model parameters for $40-\mathrm{GWd} / \mathrm{t}$ burnup, 3.79 wt $\%$ cases $\ldots \ldots \ldots$. . . . 9

4. Depletion model parameters for $45-\mathrm{GWd} / \mathrm{t}$ burnup, $4.24 \mathrm{wt} \%$ cases $\ldots \ldots \ldots$. . . . 10

5. K-infinite values for infinite array of BWR assemblies

for various burnup, enrichment, and cooling time scenarios

6. Comparison of BWR and PWR absorption rankings for actinides . . . . . . . . . 24

7. Comparison of PWR and BWR absorption rankings for fission products $\ldots \ldots \ldots 25$ 


\section{INTRODUCTION}

This report documents the work performed by ORNL for the Yucca Mountain Project (YMP) $\mathrm{M} \& \mathrm{O}$ contractor, Framatome Cogema Fuels. The goal of this work was to obtain $\mathrm{k}_{\mathrm{inf}}$ values for infinite arrays of flooded boiling-water-reactor (BWR) fuel assemblies as a function of various burnup/enrichment and cooling-time combinations. These scenarios simulate expected limiting criticality loading conditions (for a given assembly type) for drift emplacements in a repository. Upon consultation with the YMP staff, a Quad Cities BWR fuel assembly was selected as a baseline assembly. This design consists of seven axial enrichment zones, three of which contain natural uranium oxide. No attempt was made to find a "bounding" or even "typical" assembly design due to the wide variety in fuel assembly designs necessary for consideration. The current work concentrates on establishing a baseline analysis, along with a small number of sensitivity studies which can be expanded later if desired.

As a result of similar studies of this nature, several effects are known to be important in the determination of the final $\mathrm{k}_{\text {inf }}$ for spent fuel in a cask-like geometry. For a given enrichment there is an optimal burnup: for lower burnups, excess energy (and corresponding excess reactivity) is present in the fuel assembly; for larger burnups, the assembly is overburned and essentially driven by neighboring fuel assemblies. The majority of the burnup/enrichment scenarios included in this study were for some near-optimum burnup/enrichment combinations as determined from Energy Information Administration (EIA) data (see Fig. 1). Several calculations were performed for underand over-burned fuel to show these effects.

The particular primary burnup/enrichments combinations that were studied in this work include the following:
Case 1
$33 \mathrm{GWd} / \mathrm{t}$ with 2.9 wt $\%$ average enrichment
Case 2
$40 \mathrm{GWd} / \mathrm{t}$ with $3.4 \mathrm{wt} \%$ average enrichment
Case 3
$45 \mathrm{GWd} / \mathrm{t}$ with 3.8 wt $\%$ average enrichment.

Even though these burnup/enrichment combinations were obtained from the curves in Fig. 1 to be appropriate for near-optimally burned fuel, some uncertainty existed over the actual definition of the average enrichment. For one assumption, the average enrichment given is an average over the active fuel region, excluding the two top and one bottom natural uranium sections of the assembly; in the other the average is over the entire assembly. Calculations were performed for both sets of assumptions. The actual assembly contains typically ten different enrichments across an assembly, in addition to the previously mentioned axial enrichment zones. Within each of the seven axial enrichment zones, the various pin enrichments (so-called pin splits) were averaged, resulting in a single enrichment within each axial zone for all remaining calculations. Fuel rods containing Gd (i.e., Gd rods) were treated to the extent possible using standard methods.

The $\mathrm{k}_{\text {inf }}$ values for infinite arrays of BWR fuel assemblies with these characteristics and cooled for 5, 10, 20 and 40 years were evaluated in this study. To study the effects of over- and underburned fuels, cases were analyzed corresponding to average enrichments of $2.7 \mathrm{wt} \%$ and $3.1 \mathrm{wt} \%$ for $33 \mathrm{GWd} / \mathrm{t}$ burnups; $3.2 \mathrm{wt} \%$ and $3.6 \mathrm{wt} \%$ for $40 \mathrm{GWd} / \mathrm{t}$ burnups; and $3.6 \mathrm{wt} \%$ and $4.0 \mathrm{wt} \%$ for $45 \mathrm{GWd} / \mathrm{t}$ burnups. 


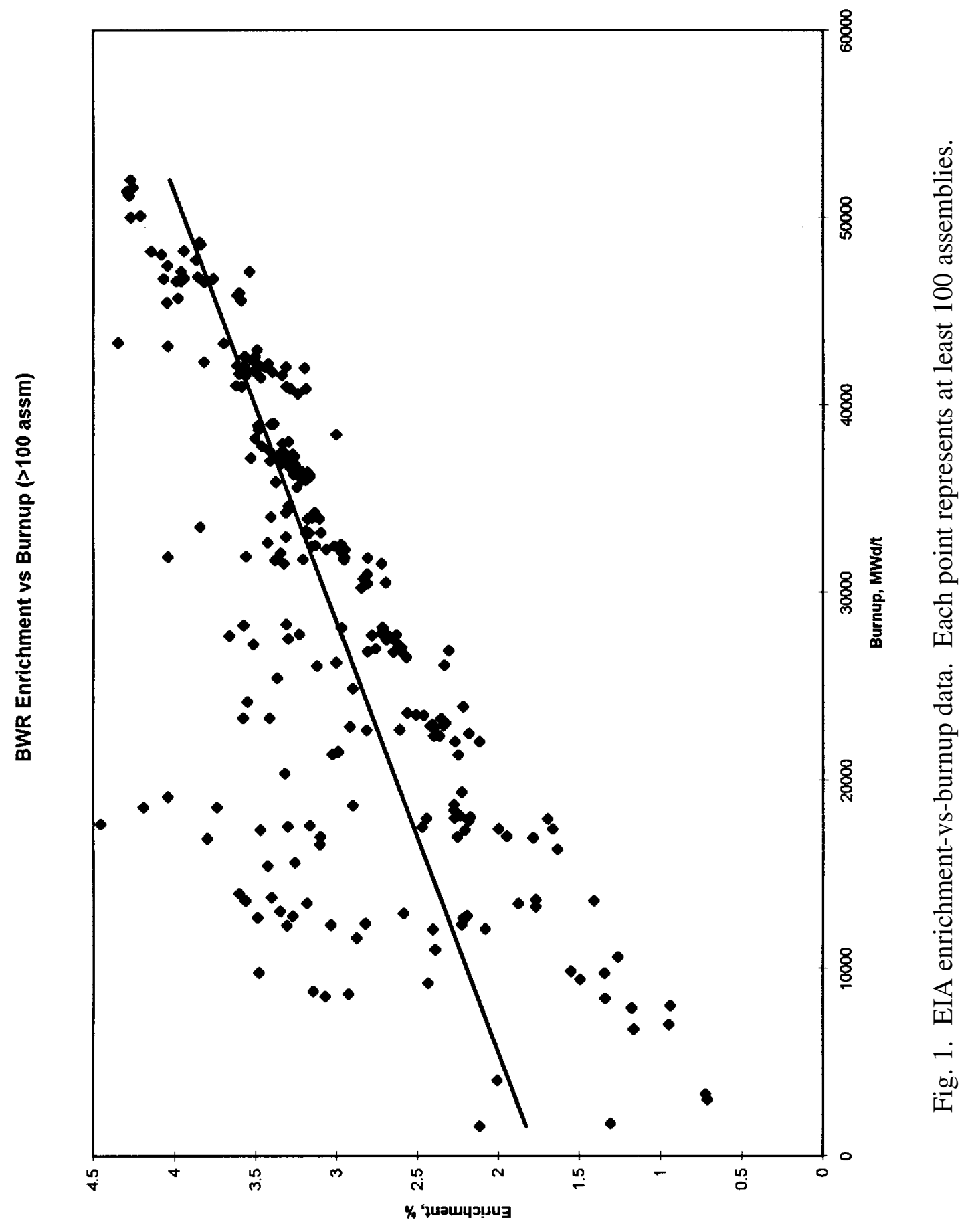




\section{BURNUP MODEL DEVELOPMENT}

The SCALE module SAS2H ${ }^{1}$ was used to obtain burnup and decay-dependent isotopics for input into multidimensional $\mathrm{k}_{\text {inf }}$ calculations. SAS2H uses a two-step approach to quantify the average fluxes and cross sections across an assembly. The first step is a pin-cell calculation which computes effective pin-lattice cross sections for input into a second calculation which determines assembly-averaged parameters while approximating the heterogenous aspects of the full assembly (i.e., water holes, Gd rods, burnable poison rods, etc.).

In this study, the fuel assembly under consideration contains seven different axial enrichment zones, as shown in Fig. 2. The isotopics were determined for each of 24 equally spaced axial nodes. For each axial node the power history and assembly model were specified, with the resulting isotopics

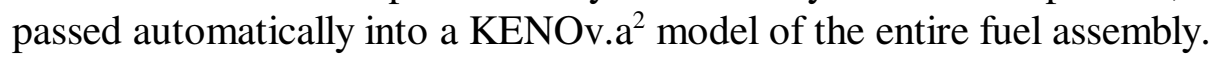

The pin-cell and full-assembly models used in SAS2H are given in Table 1. In each case, the radii shown in Table 1 are determined based on the pellet and clad diameters, and pitch for the pin-cell model; and additionally the number of Gd rods, the channel dimensions, and the assembly pitch for the assembly models. For the assembly model, a Gd rod is modeled explicitly with dimensions identical to the pin-cell model in Table 1, but surrounded by a fraction of the remaining assembly, channel, and channel moderator. The fraction depends on the number of $\mathrm{Gd}$ rods in each axial section of the assembly (i.e., 1/9 if nine $\mathrm{Gd}$ rods, and 1/7 if seven Gd rods). In this manner, the moderatorto-fuel volume fractions are conserved for the assembly.

The power history for all calculations consisted of three cycles of length 333.33 days, zero days downtime between cycles, and a variable specific power corresponding to the desired burnup. This specific power for each node is assumed to be constant over the life of the assembly. This assumption is felt to be appropriate for near fully-burned assemblies as treated in this work. Obviously, for severely under-burned assemblies, this assumption would not be valid. Using this power history scheme, numerical values of the specific power in MW/t and the total burnup in GWd/t are equivalent. The specific power (and burnup) by axial node were obtained from the burnup shape (see Fig. 3) as provided by YMP staff ${ }^{3,4}$ and renormalizing to the overall desired assembly burnup. The resulting burnups/specific powers for each axial node are given in Tables 2 through 4 for burnups of 33,40 , and $45 \mathrm{GWd} / \mathrm{t}$, respectively.

The procedure for obtaining averaged enrichments for each of the seven axial enrichment zones was previously discussed. However, to study various burnup/enrichment combinations, these enrichment profiles were renormalized to other average enrichments. However, in all cases the

enrichments in the natural uranium portions of the fuel remained constant. As can be seen in Tables 2 through 4 the enrichments by node are normalized to an assembly average of 2.9, 3.4 and $3.8 \mathrm{wt} \%$, respectively. This renormalization allows these calculations to retain the axial power flattening characteristics of the natural uranium reflectors, while allowing for variable enrichments in the remaining portions of the fuel assembly.

The moderator densities were determined in the following manner using the YMP-supplied void fractions shown in Fig. 4. The reactor operating pressure was assumed to be 1040 psia ${ }^{5}$ with saturation fluid and vapor densities of $0.7365 \mathrm{~g} / \mathrm{cc}$ and $0.0377 \mathrm{~g} / \mathrm{cc}$, respectively. The effective water density for each node (see Fig. 4 and Tables 2 through 4) was then determined from the following relationship:

$$
\rho_{\text {water }}=0.0377 \mathrm{~V}_{\mathrm{f}}+0.7365\left(1-\mathrm{V}_{\mathrm{f}}\right) \text {, where } \mathrm{V}_{\mathrm{f}} \text { is the void fraction. }
$$




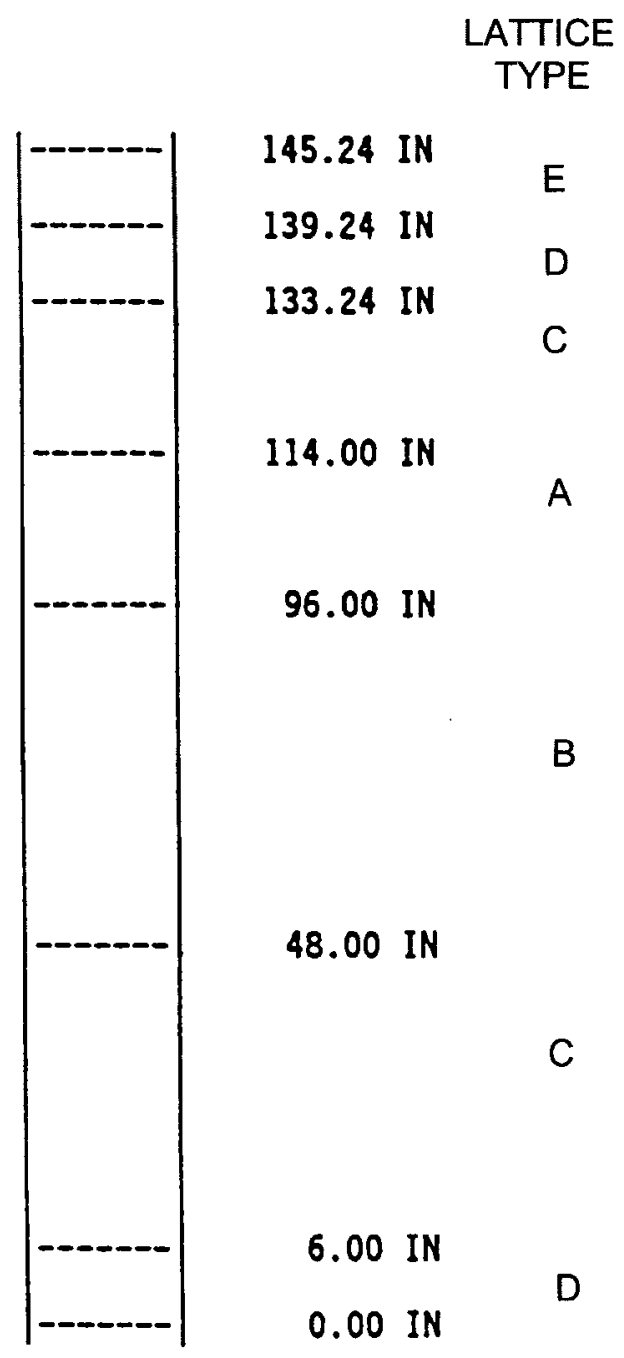

\section{AVERAGE ENRICHMENT $=3.103$ Wt $\% \mathrm{U}-235$ \\ BUNDLE MASS $=172.948 \mathrm{kgs}$}

Fig. 2. Axial description of BWR assembly used in this work. 
Table 1a. Fuel-pin-cell mixing table

\begin{tabular}{ccccccc}
\hline $\begin{array}{c}\text { Mixture } \\
\text { No. }\end{array}$ & Component & \multicolumn{1}{c}{ Wt $\%$} & Density ${ }^{a}$ & VF & T,K & $\begin{array}{c}\text { Radius } \\
(\mathrm{cm})\end{array}$ \\
\hline 1 & $\mathrm{UO}_{2}$ & & 9.87 & 1.0 & 840 & 0.53213 \\
& ${ }^{234} \mathrm{U}$ & $0.007731\left({ }^{235} \mathrm{U}\right)^{1.0837}$ & & & & \\
& ${ }^{235} \mathrm{U}$ & $2.7-4.0$ & & & & \\
& ${ }^{236} \mathrm{U}$ & $0.0046\left({ }^{235} \mathrm{U}\right)$ & & & & \\
& ${ }^{238} \mathrm{U}$ & Remainder & & 1.0 & 620 & 0.61341 \\
& Zircaloy & & & Variable & Variable & 0.91715 \\
\hline
\end{tabular}

${ }^{a}$ Input as keyword DEN=.

Table 1b. Larger-unit-cell mixing table for lattice type A

\begin{tabular}{|c|c|c|c|c|c|c|}
\hline $\begin{array}{c}\text { Mixture } \\
\text { No. }\end{array}$ & Component & Wt $\%$ & Density $^{a}$ & VF & $\mathrm{T}, \mathrm{K}$ & $\begin{array}{c}\text { Radius } \\
(\mathrm{cm})\end{array}$ \\
\hline \multirow[t]{9}{*}{9} & $\mathrm{UO}_{2}$ & & 9.87 & 1.0 & 840 & 0.53213 \\
\hline & $\mathrm{Gd}_{2} \mathrm{O}_{3}$ & & 9.87 & 0.03 & & \\
\hline & ${ }^{154} \mathrm{Gd}$ & 2.18 & & & & \\
\hline & ${ }^{155} \mathrm{Gd}$ & 14.80 & & & & \\
\hline & ${ }^{156} \mathrm{Gd}$ & 20.47 & & & & \\
\hline & ${ }^{157} \mathrm{Gd}$ & 15.65 & & & & \\
\hline & ${ }^{158} \mathrm{Gd}$ & 24.84 & & & & \\
\hline & ${ }^{160} \mathrm{Gd}$ & 21.86 & & & & \\
\hline & $\mathrm{O}$ & $150.00^{b}$ & & & & \\
\hline 2 & Zircaloy & & & 1.0 & 620 & 0.61341 \\
\hline 3 & $\mathrm{H}_{2} \mathrm{O}$ & & & Variable & Variable & 0.91715 \\
\hline 500 & \multicolumn{5}{|c|}{ (Smeared fuel calculated by SAS2) } & 2.3681 \\
\hline 10 & Zircaloy & & & 1.0 & 558 & 2.4079 \\
\hline 11 & $\mathrm{H}_{2} \mathrm{O}$ & & & 0.743 & 552 & 2.8661 \\
\hline
\end{tabular}

${ }^{a}$ Input as keyword DEN=.

${ }^{b}$ Equivalent oxygen, considering total gadolinium $=100$. 
Table 1c. Larger-unit-cell mixing table for lattice types B, C

\begin{tabular}{|c|c|c|c|c|c|c|}
\hline $\begin{array}{c}\text { Mixture } \\
\text { No. }\end{array}$ & Component & Wt $\%$ & Density $^{a}$ & VF & $\mathrm{T}, \mathrm{K}$ & $\begin{array}{c}\text { Radius } \\
(\mathrm{cm})\end{array}$ \\
\hline \multirow[t]{9}{*}{9} & $\mathrm{UO}_{2}$ & & 9.87 & 1.0 & 840 & 0.53213 \\
\hline & $\mathrm{Gd}_{2} \mathrm{O}_{3}$ & & 9.87 & 0.03 & & \\
\hline & ${ }^{154} \mathrm{Gd}$ & 2.18 & & & & \\
\hline & ${ }^{155} \mathrm{Gd}$ & 14.80 & & & & \\
\hline & ${ }^{156} \mathrm{Gd}$ & 20.47 & & & & \\
\hline & ${ }^{157} \mathrm{Gd}$ & 15.65 & & & & \\
\hline & ${ }^{158} \mathrm{Gd}$ & 24.84 & & & & \\
\hline & ${ }^{160} \mathrm{Gd}$ & 21.86 & & & & \\
\hline & $\mathrm{O}$ & $150.00^{b}$ & & & & \\
\hline 2 & Zircaloy & & & 1.0 & 620 & 0.61341 \\
\hline 3 & $\mathrm{H}_{2} \mathrm{O}$ & & & Variable & Variable & 0.91715 \\
\hline 500 & \multicolumn{5}{|c|}{ (Smeared fuel calculated by SAS2) } & 2.6851 \\
\hline 10 & Zircaloy & & & 1.0 & 588 & 2.7303 \\
\hline 11 & $\mathrm{H}_{2} \mathrm{O}$ & & & 0.743 & 552 & 3.2498 \\
\hline
\end{tabular}

${ }^{a}$ Input as keyword DEN=.

${ }^{b}$ Equivalent oxygen, considering total gadolinium $=100$.

Table 1d. Larger-unit-cell mixing table for lattice types D, E

\begin{tabular}{rlcrc}
\hline $\begin{array}{c}\text { Mixture } \\
\text { No. }\end{array}$ & Component & VF & T,K & $\begin{array}{c}\text { Radius } \\
(\mathrm{cm})\end{array}$ \\
\hline 3 & $\mathrm{H}_{2} \mathrm{O}$ & 0.743 & 552 & 1.8343 \\
500 & (Smeared fuel calculated by SAS2) & 7.3372 \\
10 & Zircaloy & 1.0 & 588 & 7.4529 \\
11 & $\mathrm{H}_{2} \mathrm{O}$ & 0.743 & 552 & 8.5983 \\
\hline
\end{tabular}




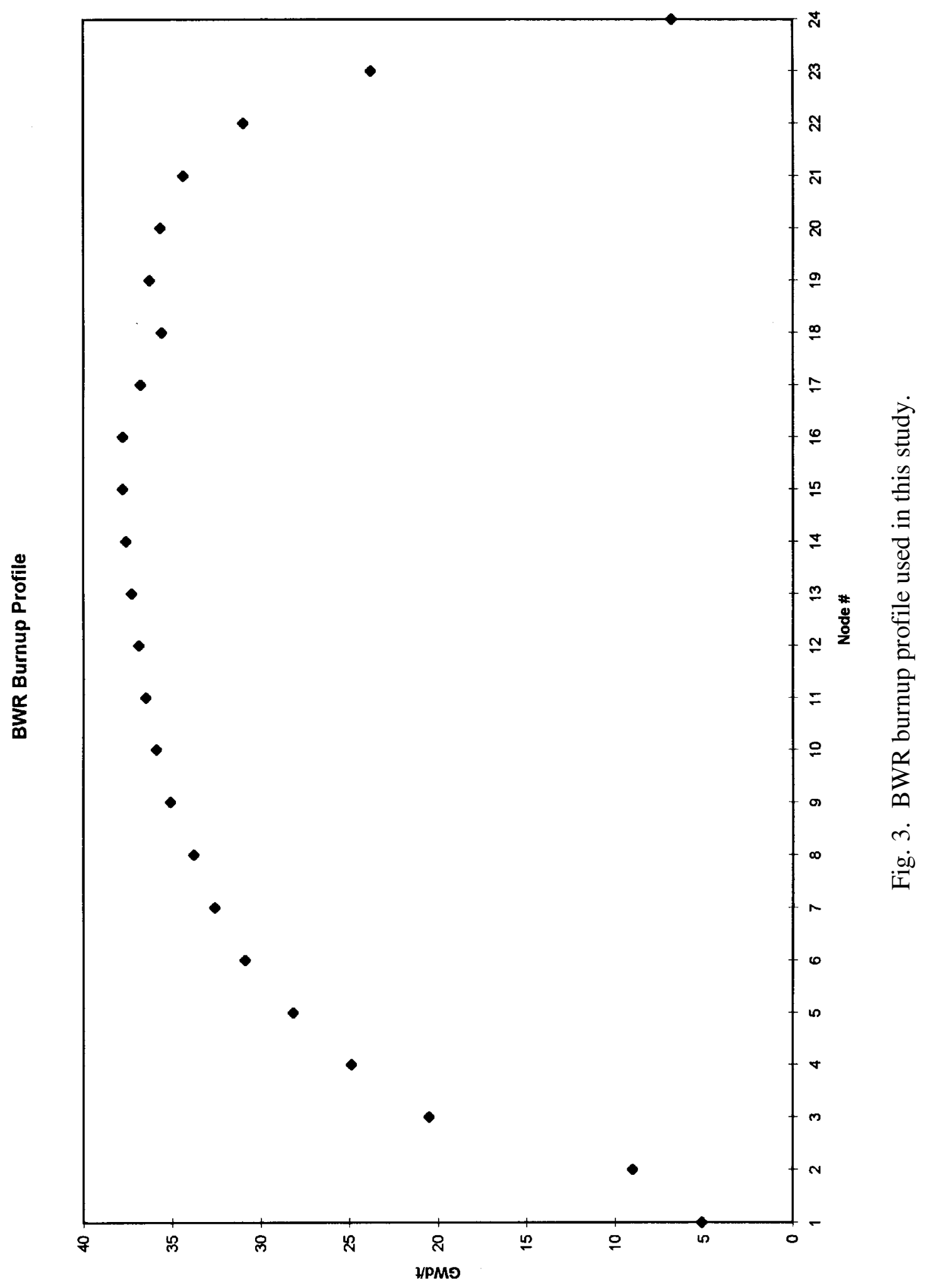


Table 2. Depletion model parameters for 33-GWd/t burnup, $3.21 \mathrm{wt} \%$ cases

\begin{tabular}{lccccc}
\hline Cell No. & $\begin{array}{c}\text { Midpoint } \\
\text { (cm from bottom) }\end{array}$ & $\begin{array}{c}\text { Burnup } \\
(\mathrm{GWd} / \mathrm{t})\end{array}$ & $\begin{array}{c}\text { Moderator } \\
\text { density }\end{array}$ & $\begin{array}{c}\text { Moderator } \\
\text { temperature }\end{array}$ & Enrichment \\
\hline 1 & 7.686 & 7.478 & 0.754 & 548.561 & 0.710 \\
2 & 23.057 & 26.200 & 0.749 & 550.244 & 3.132 \\
3 & 38.428 & 34.113 & 0.732 & 551.927 & 3.132 \\
4 & 53.799 & 37.818 & 0.699 & 553.609 & 3.132 \\
5 & 69.171 & 39.287 & 0.655 & 555.292 & 3.132 \\
6 & 84.542 & 39.880 & 0.608 & 556.975 & 3.132 \\
7 & 99.913 & 39.093 & 0.562 & 557.990 & 3.132 \\
8 & 115.284 & 40.453 & 0.520 & 558.000 & 3.132 \\
9 & 130.656 & 41.559 & 0.482 & 558.000 & 3.283 \\
10 & 146.027 & 41.569 & 0.449 & 558.000 & 3.283 \\
11 & 161.398 & 41.372 & 0.419 & 558.000 & 3.283 \\
12 & 176.769 & 41.027 & 0.393 & 558.000 & 3.283 \\
13 & 192.141 & 40.592 & 0.370 & 558.000 & 3.283 \\
14 & 207.512 & 40.071 & 0.350 & 558.000 & 3.283 \\
15 & 222.883 & 39.425 & 0.332 & 558.000 & 3.283 \\
16 & 238.254 & 38.563 & 0.316 & 558.000 & 3.283 \\
17 & 253.626 & 37.199 & 0.302 & 558.000 & 3.283 \\
18 & 268.997 & 35.792 & 0.289 & 558.000 & 3.283 \\
19 & 284.368 & 34.000 & 0.277 & 558.000 & 3.283 \\
20 & 299.739 & 31.050 & 0.267 & 558.000 & 3.132 \\
21 & 315.111 & 27.376 & 0.258 & 558.000 & 3.132 \\
22 & 330.482 & 22.546 & 0.250 & 558.000 & 3.132 \\
23 & 345.853 & 9.904 & 0.246 & 558.000 & 0.710 \\
24 & 361.224 & 5.632 & 0.243 & 558.000 & 0.710 \\
\hline
\end{tabular}


Table 3. Depletion model parameters for $40-\mathrm{GWd} / \mathrm{t}$ burnup, 3.79 wt $\%$ cases

\begin{tabular}{lcrrrr}
\hline Cell No. & $\begin{array}{c}\text { Midpoint } \\
\text { (cm from bottom) }\end{array}$ & $\begin{array}{c}\text { Burnup } \\
(\mathrm{GWd} / \mathrm{t})\end{array}$ & $\begin{array}{c}\text { Moderator } \\
\text { density }\end{array}$ & $\begin{array}{c}\text { Moderator } \\
\text { temperature }\end{array}$ & Enrichment \\
\hline 1 & 7.686 & 9.064 & 0.754 & 548.561 & 0.710 \\
2 & 23.057 & 31.758 & 0.749 & 550.244 & 3.697 \\
3 & 38.428 & 41.350 & 0.732 & 551.927 & 3.697 \\
4 & 53.799 & 45.840 & 0.699 & 553.609 & 3.697 \\
5 & 69.171 & 47.620 & 0.655 & 555.292 & 3.697 \\
6 & 84.542 & 48.340 & 0.608 & 556.975 & 3.697 \\
7 & 99.913 & 47.386 & 0.562 & 557.990 & 3.697 \\
8 & 115.284 & 49.034 & 0.520 & 558.000 & 3.697 \\
9 & 130.656 & 50.375 & 0.482 & 558.000 & 3.876 \\
10 & 146.027 & 50.387 & 0.449 & 558.000 & 3.876 \\
11 & 161.398 & 50.148 & 0.419 & 558.000 & 3.876 \\
12 & 176.769 & 49.730 & 0.393 & 558.000 & 3.876 \\
13 & 192.141 & 49.202 & 0.370 & 558.000 & 3.876 \\
14 & 207.512 & 48.570 & 0.350 & 558.000 & 3.876 \\
15 & 222.883 & 47.788 & 0.332 & 558.000 & 3.876 \\
16 & 238.254 & 46.744 & 0.316 & 558.000 & 3.876 \\
17 & 253.626 & 45.090 & 0.302 & 558.000 & 3.876 \\
18 & 268.997 & 43.384 & 0.289 & 558.000 & 3.876 \\
19 & 284.368 & 41.212 & 0.277 & 558.000 & 3.876 \\
20 & 299.739 & 37.636 & 0.267 & 558.000 & 3.697 \\
21 & 315.111 & 33.182 & 0.258 & 558.000 & 3.697 \\
22 & 330.482 & 27.329 & 0.250 & 558.000 & 3.697 \\
23 & 345.853 & 12.005 & 0.246 & 558.000 & 0.710 \\
24 & 361.224 & 6.827 & 0.243 & 558.000 & 0.710 \\
\hline
\end{tabular}


Table 4. Depletion model parameters for $45-\mathrm{GWd} / \mathrm{t}$ burnup, $4.24 \mathrm{wt} \%$ cases

\begin{tabular}{cccccc}
\hline Cell No. & $\begin{array}{c}\text { Midpoint } \\
\text { (cm from bottom })\end{array}$ & $\begin{array}{c}\text { Burnup } \\
(\mathrm{GWd} / \mathrm{t})\end{array}$ & $\begin{array}{c}\text { Moderator } \\
\text { density }\end{array}$ & $\begin{array}{c}\text { Moderator } \\
\text { temperature }\end{array}$ & Enrichment \\
\hline 1 & 7.686 & 10.197 & 0.754 & 548.561 & 0.710 \\
2 & 23.057 & 35.728 & 0.749 & 550.244 & 4.136 \\
3 & 38.428 & 46.518 & 0.732 & 551.927 & 4.136 \\
4 & 53.799 & 51.570 & 0.699 & 553.609 & 4.136 \\
5 & 69.171 & 53.573 & 0.655 & 555.292 & 4.136 \\
6 & 84.542 & 54.382 & 0.608 & 556.975 & 4.136 \\
7 & 99.913 & 53.309 & 0.562 & 557.990 & 4.136 \\
8 & 115.284 & 55.163 & 0.520 & 558.000 & 4.136 \\
9 & 130.656 & 56.672 & 0.482 & 558.000 & 4.337 \\
10 & 146.027 & 56.685 & 0.449 & 558.000 & 4.337 \\
11 & 161.398 & 56.417 & 0.419 & 558.000 & 4.337 \\
12 & 176.769 & 55.946 & 0.393 & 558.000 & 4.337 \\
13 & 192.141 & 55.352 & 0.370 & 558.000 & 4.337 \\
14 & 207.512 & 54.642 & 0.350 & 558.000 & 4.337 \\
15 & 222.883 & 53.762 & 0.332 & 558.000 & 4.337 \\
16 & 238.254 & 52.587 & 0.316 & 558.000 & 4.337 \\
17 & 253.626 & 50.726 & 0.302 & 558.000 & 4.337 \\
18 & 268.997 & 48.807 & 0.289 & 558.000 & 4.337 \\
19 & 284.368 & 46.364 & 0.277 & 558.000 & 4.337 \\
20 & 299.739 & 42.340 & 0.267 & 558.000 & 4.136 \\
21 & 315.111 & 37.330 & 0.258 & 558.000 & 4.136 \\
22 & 330.482 & 30.745 & 0.250 & 558.000 & 4.136 \\
23 & 345.853 & 13.505 & 0.246 & 558.000 & 0.710 \\
24 & 361.224 & 7.680 & 0.243 & 558.000 & 0.710 \\
\hline
\end{tabular}

A fuel temperature of $840 \mathrm{~K}$ and a clad temperature of $620 \mathrm{~K}$ were taken from sample problem 4 in the SCALE SAS2 manual. The moderator temperature ${ }^{6}$ was assumed to be represented by

$$
\begin{aligned}
\mathrm{T}_{\text {fuel }} & =0.11 \mathrm{z}+547 & \text { if } \mathrm{z}<93.98 \mathrm{~cm} \\
= & 558 & \text { if } \mathrm{z}>93.98 \mathrm{~cm} .
\end{aligned}
$$

The resulting moderator temperatures are given in Tables 2 through 4 for each of the 24 axial nodes used in this analysis. 


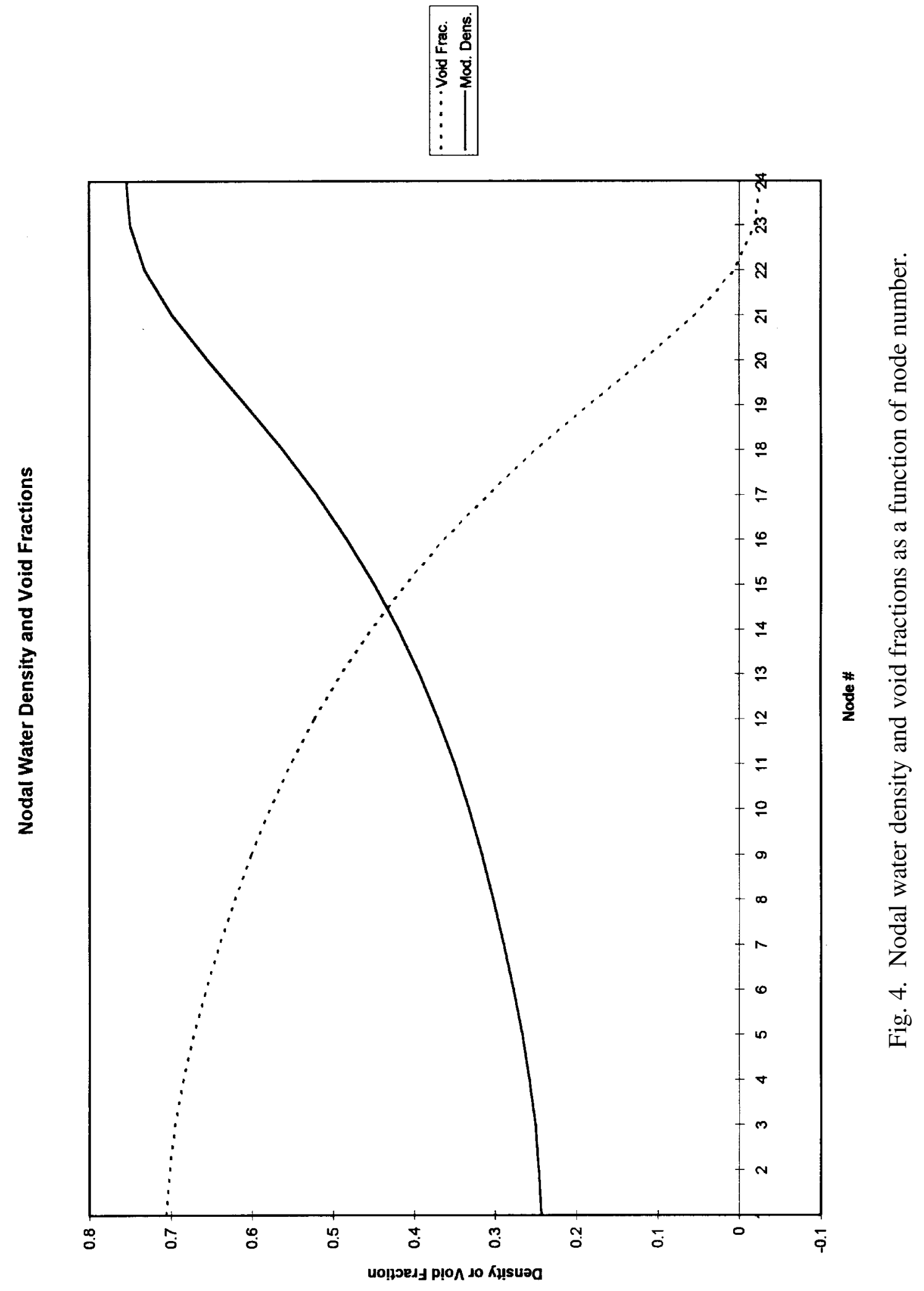




\section{KENO MODEL DESCRIPTION}

The KENO V.a model for the BWR fuel assemblies consists of an $8 \times 8$ array of fuel pins with dimensions as given for the pin-cell case in Table 1. The fuel pins from the central four locations are removed and contain only water, as shown in Fig. 5. The positions that contain Gd rods are modeled explicitly, as seen in Fig. 5. The fuel assembly nodes containing $\mathrm{Gd}$ rods have either 7 or $9 \mathrm{Gd}$ rods per node. For simplicity and conservatism, only $7 \mathrm{Gd}$ rods per node were modeled in KENO. The $2 \mathrm{Gd}$ rods omitted in the three-dimensional models were replaced by standard fuel pins. As stated previously, only an average fuel enrichment is used and therefore, all non-Gd rods contain the same burned fuel concentrations; the Gd rods contain the same burned fuel material plus the remaining Gd in the Gd rods. The fuel assembly can or channel is also modeled with inside dimensions of 13.13 by $13.13 \mathrm{~cm}$ and outside dimensions of 13.34 by $13.34 \mathrm{~cm}$, and an assembly pitch of $15.24 \mathrm{~cm}$. The boundary conditions specify reflected surfaces on four sides of the fuel assembly, with the top and bottom reflected with $30 \mathrm{~cm}$ of water, which effectively gives an infinite array of these fuel assemblies. 


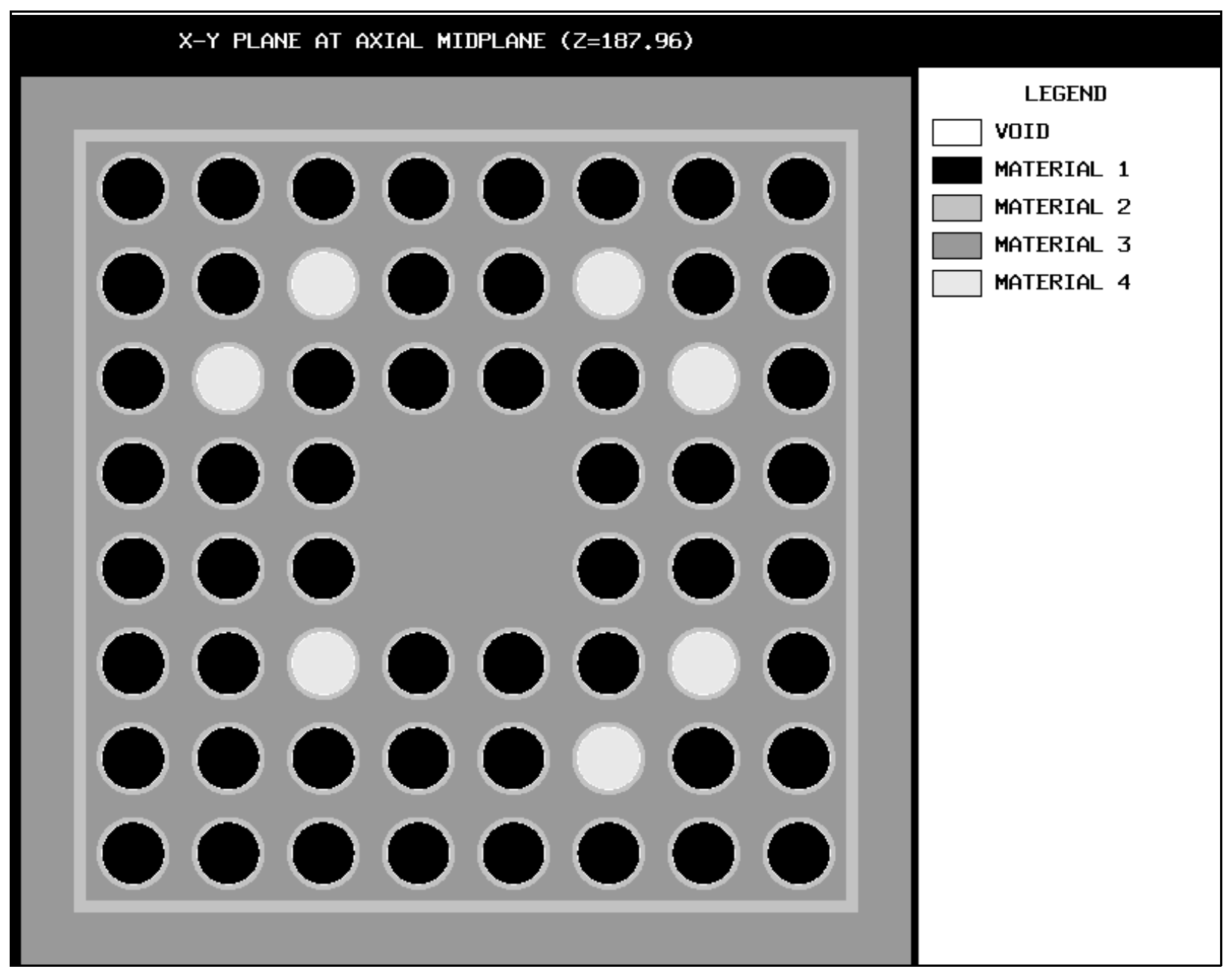

Fig. 5. Plot showing BWR assembly geometry. 


\section{PROCESSING CODE DESCRIPTION}

In order to facilitate the generation of $\mathrm{k}_{\text {inf }}$ values for the various burnup/enrichment combinations with 24-node-dependent isotopics, a previously developed internal program was modified to assemble the appropriate SCALE input files. This program, termed BWRP, performs the following series of operations:

1. reads the number of nodes, desired burnup, enrichment, cooling time, and enrichment/burnup profile options;

2. correlates equally spaced nodes to built-in seven axial enrichment zones;

3. renormalizes built-in burnup and enrichment profiles to input values of burnup and average enrichment;

4. sets nodal water temperatures and densities from built-in data;

5. sets up and executes a SAS2 case for each node;

6. after each SAS2 case, the module SNIKR reads SAS2 output and constructs SCALE standard composition and KENO mixing-table input; and

7. using the SCALE standard composition data for each node, sets up a final input stream which executes CSASN to process cross sections for each node, sets up and executes WAX to combine cross-section libraries for node, then sets up and runs final KENO case with combined cross-section library and previously prepared KENO mixing-table data.

The only user interaction with BWRP occurs in step 1. All other operations are performed within a single execution of the program. Although the code has some inherent inefficiencies (e.g., the entire procedure must be repeated for each decay time), the user time per problem is minimal. 


\section{K-INFINITE RESULTS}

The k-infinite results for an infinite array of BWR assemblies with "typical" burnup/enrichment parameters are given in Table 5 and Figs. 6 and 7 as a function of cooling time after end of life (EOL). The results shown in Fig. 6 correspond to a definition of assembly-average enrichments, where the natural uranium reflectors are omitted from the average; thus the nonreflector enrichments for Fig. 6 are effectively about $10 \%$ lower than those used for Fig. 7, which include the reflectors in the average. The corresponding $\mathrm{k}_{\text {inf }}$ results in Fig. 7 are about $4 \%$ higher than those shown in Fig. 6. In Fig. 8 the $\mathrm{k}_{\text {inf }}$ results are trended with high, average, and low enrichments. In all cases, the low enrichment is $0.02 \mathrm{wt} \%$ less than the typical value, and the high enrichment is $0.02 \mathrm{wt} \%$ higher than typical. These differences amount to between 5 and $7 \%$ in the enrichments. It can be seen from these plots that the variation of $k_{\text {inf }}$ values with initial enrichment is nearly linear since for a given burnup the change in $\mathrm{k}_{\text {inf }}$ should be similar between several systems. The magnitude of the ending $\mathrm{k}_{\text {inf }}$ values should depend primarily on the amount of initial excess reactivity.

The obvious conclusions are that the value of $\mathrm{k}_{\text {inf }}$ decreases with decay (due primarily to the loss of ${ }^{241} \mathrm{Pu}$ ) up to 40 years of cooling time, decreases with burnup for a given enrichment, and increases with higher enrichments for the same burnup.

Following the generation of the results reported above, a series of sensitivity studies were performed to determine the effect of removal of the $\mathrm{Gd}$ rods from the final $\mathrm{k}_{\mathrm{inf}}$ calculations, and the effect of lower specific power/longer burn times for the same integral burnup. In Fig. 9, the $\mathrm{k}_{\text {inf }}$ results are presented for the $45 \mathrm{GWd} / \mathrm{t}$ and $3.8 \mathrm{wt} \%$ case with and without Gd rods in the final 3-D calculation. The results show that the effect of the omission of the Gd rods from the final calculation is an increase of approximately 0.4 to $0.5 \%$ in $\mathrm{k}_{\text {inf }}$ for the cases considered with cooling times between 5 and 40 years. This increase in $\mathrm{k}_{\mathrm{inf}}$ is due to simply the removal of a poison from the final $\mathrm{k}$ calculation, since the depletion analyses are identical for the two cases.

The effect of a decrease in the specific power input from $45 \mathrm{MW} / \mathrm{t}$ to $40 \mathrm{MW} / \mathrm{t}$ for the $45 \mathrm{GWd} / \mathrm{t}$ and $3.8 \mathrm{wt} \%$ case was an increase in the value of $\mathrm{k}_{\mathrm{inf}}$ from 0.9147 to 0.9163 . Although a very small change, the increase is consistent with the results from a previous study ${ }^{7}$ where decreased specific power levels led to increased $\mathrm{k}_{\mathrm{inf}}$ values. This increase in $\mathrm{k}_{\mathrm{inf}}$ is caused by the reduced equilibrium fission product concentrations resulting from reduced specific powers. 
Table 5. The k-infinite values ${ }^{\mathrm{a}}$ for an infinite array of BWR assemblies for various burnup, enrichment, and cooling-time scenarios

\begin{tabular}{|c|c|c|c|c|c|}
\hline \multirow{2}{*}{$\begin{array}{l}\text { Assembly } \\
\text { average } \\
\text { enrichment } \\
\text { (wt \%) }\end{array}$} & \multirow[b]{2}{*}{$\begin{array}{l}\text { Burnup/enrichment } \\
(\mathrm{GWd} / \mathrm{t} / \mathrm{wt} \%)\end{array}$} & \multicolumn{4}{|c|}{ Cooling time (years) } \\
\hline & & 5 & 10 & 20 & 40 \\
\hline 2.63 & $33 / 2.90$ & 0.9366 & 0.9161 & 0.8947 & 0.8754 \\
\hline 3.06 & $40 / 3.40$ & 0.9321 & 0.9091 & 0.8860 & 0.8645 \\
\hline 3.41 & $45 / 3.80$ & 0.9324 & 0.9097 & 0.8833 & 0.8628 \\
\hline 2.45 & $33 / 2.70$ & 0.9106 & 0.8906 & 0.8672 & 0.8472 \\
\hline 2.80 & $33 / 3.10$ & 0.9613 & 0.9417 & 0.9210 & 0.9034 \\
\hline 2.89 & $40 / 3.20$ & 0.9085 & 0.8866 & 0.8603 & 0.8395 \\
\hline 3.24 & $40 / 3.60$ & 0.9541 & 0.9328 & 0.9095 & 0.8901 \\
\hline 3.24 & $45 / 3.60$ & 0.9111 & 0.8865 & 0.8588 & 0.8375 \\
\hline 3.59 & $45 / 4.00$ & 0.9540 & 0.9313 & 0.9060 & 0.8859 \\
\hline 2.90 & $33 / 3.21$ & 0.9750 & 0.9561 & 0.9346 & 0.9184 \\
\hline 3.40 & $40 / 3.79$ & 0.9753 & 0.9553 & 0.9314 & 0.9138 \\
\hline 3.80 & $45 / 4.24$ & 0.9788 & 0.9569 & 0.9327 & 0.9135 \\
\hline
\end{tabular}

${ }^{a}$ The k-infinite values in this table may be approximately represented by the following equation: $\mathrm{k}=0.9683+0.1197 \mathrm{E}-0.0315 \ln (\mathrm{T})-0.00986 \mathrm{~B}$, where $\mathrm{E}, \mathrm{T}$, and $\mathrm{B}$ are the values of enrichment, cooling time, and burnup, respectively. 


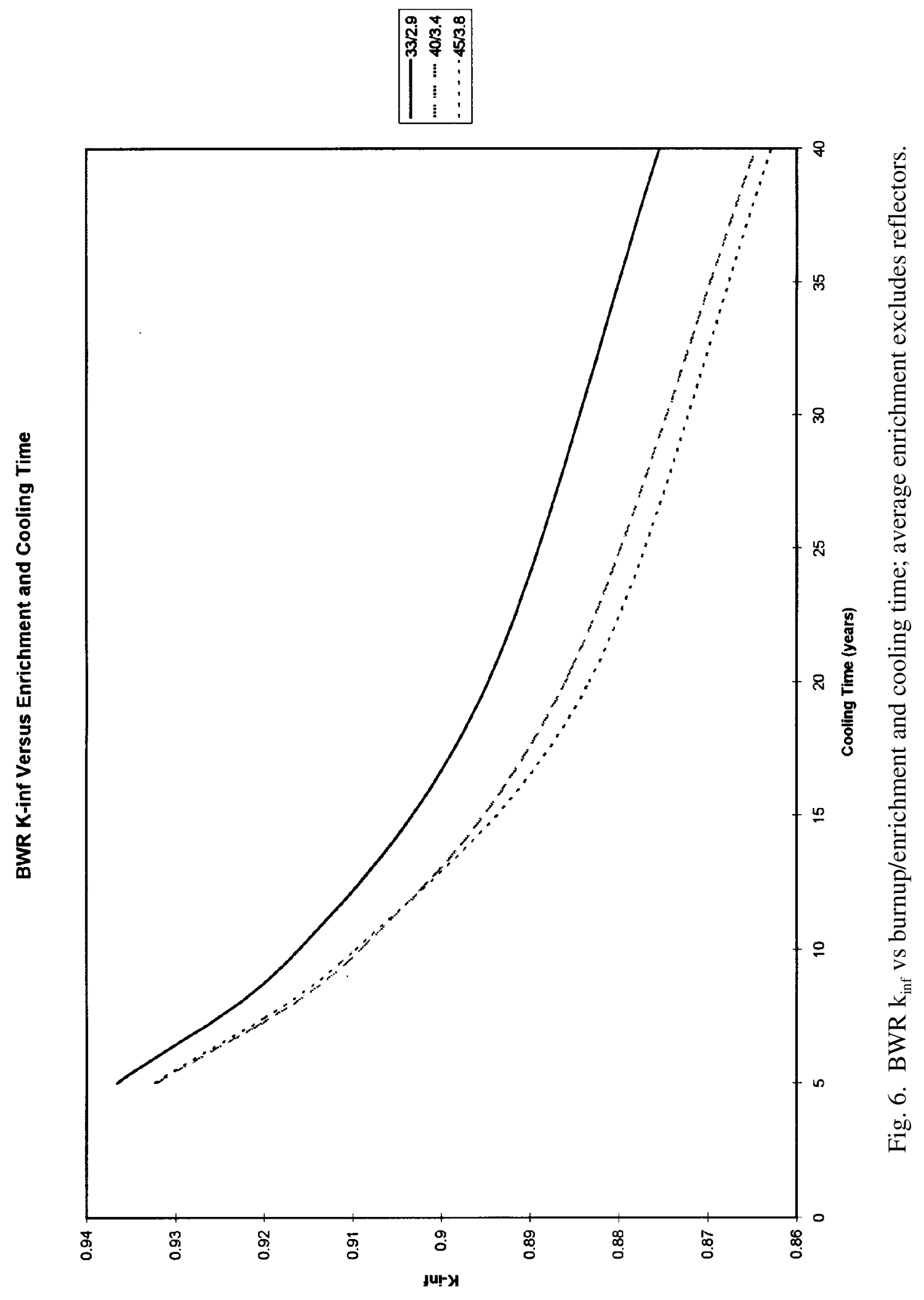




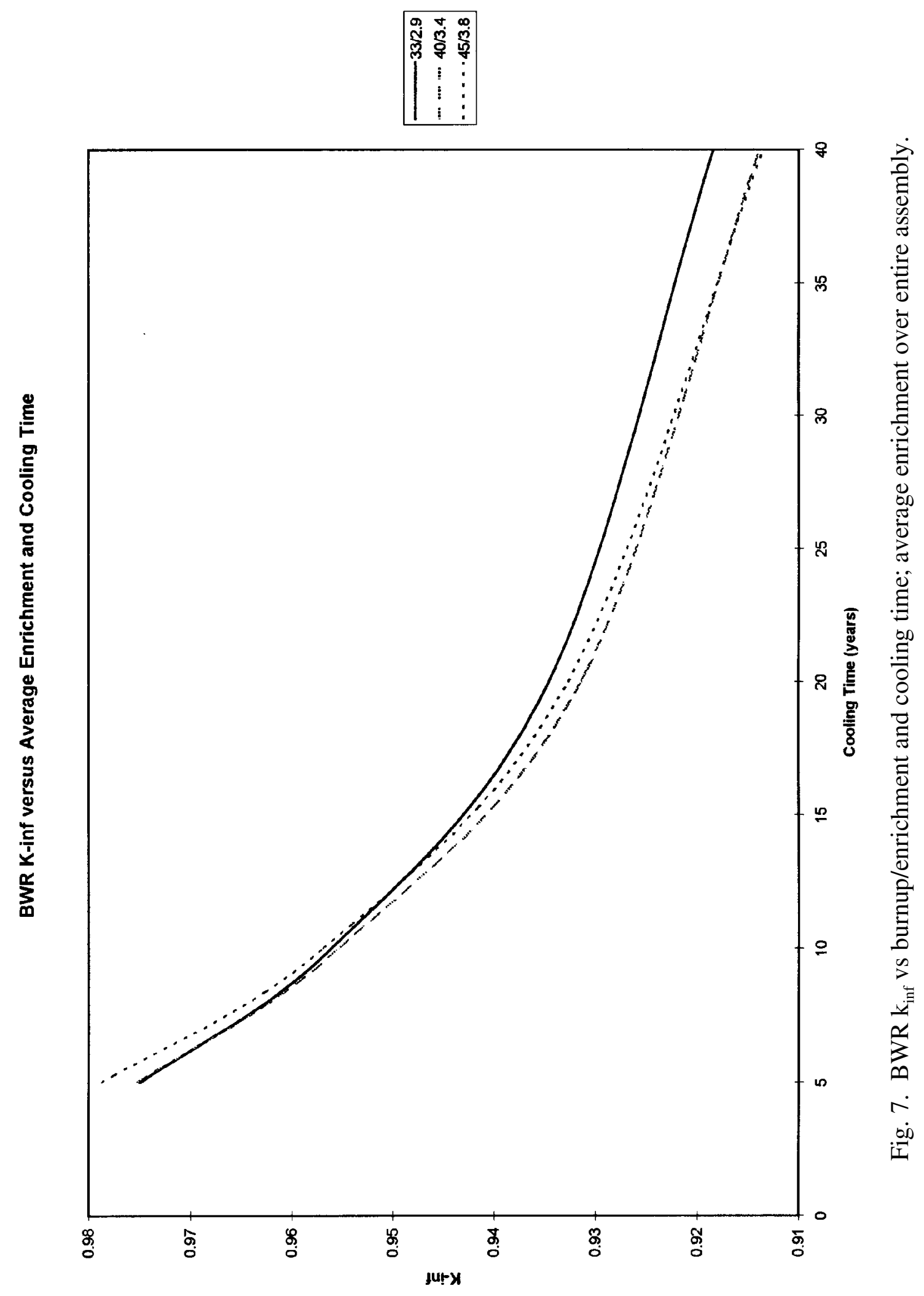




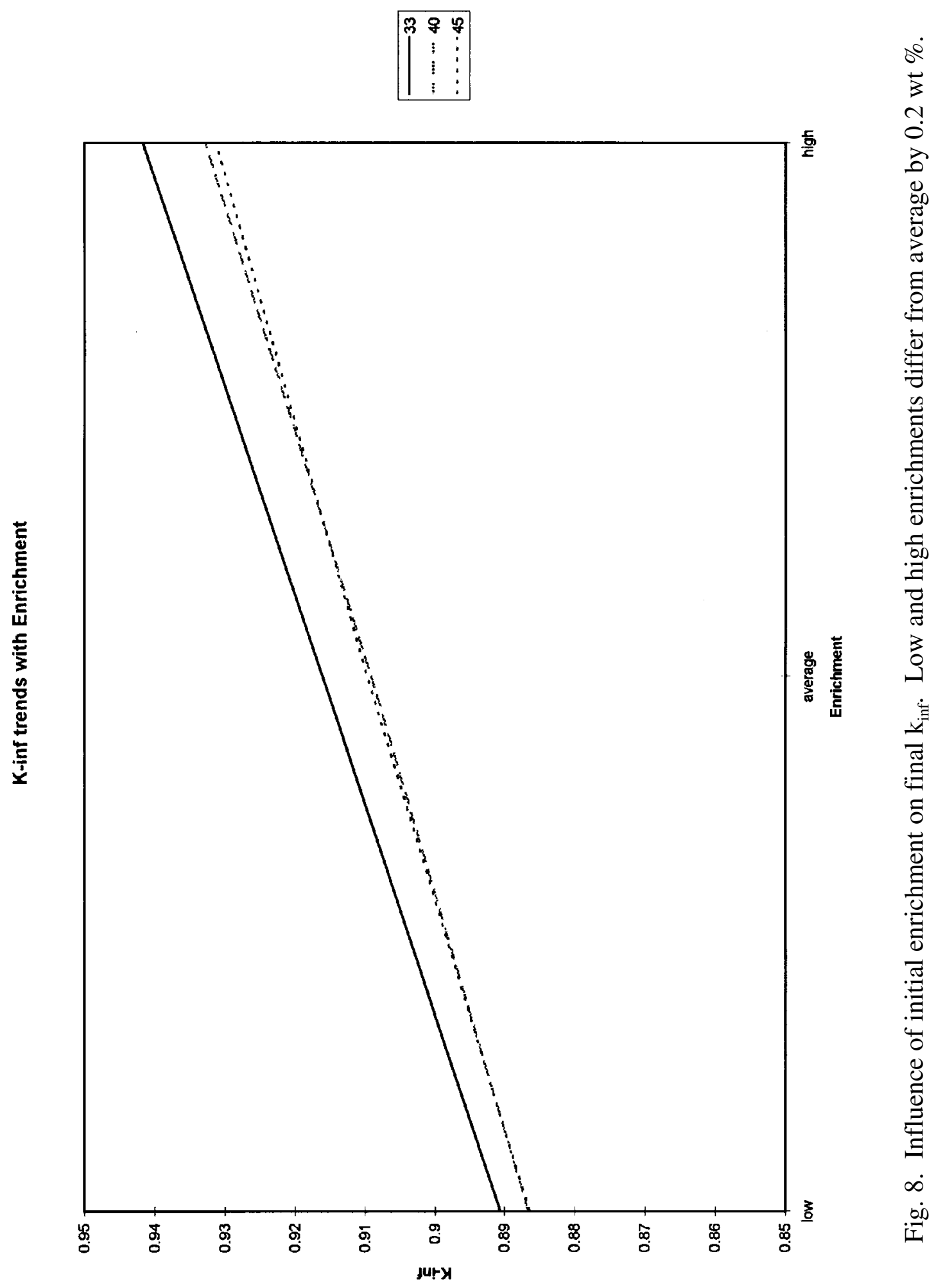




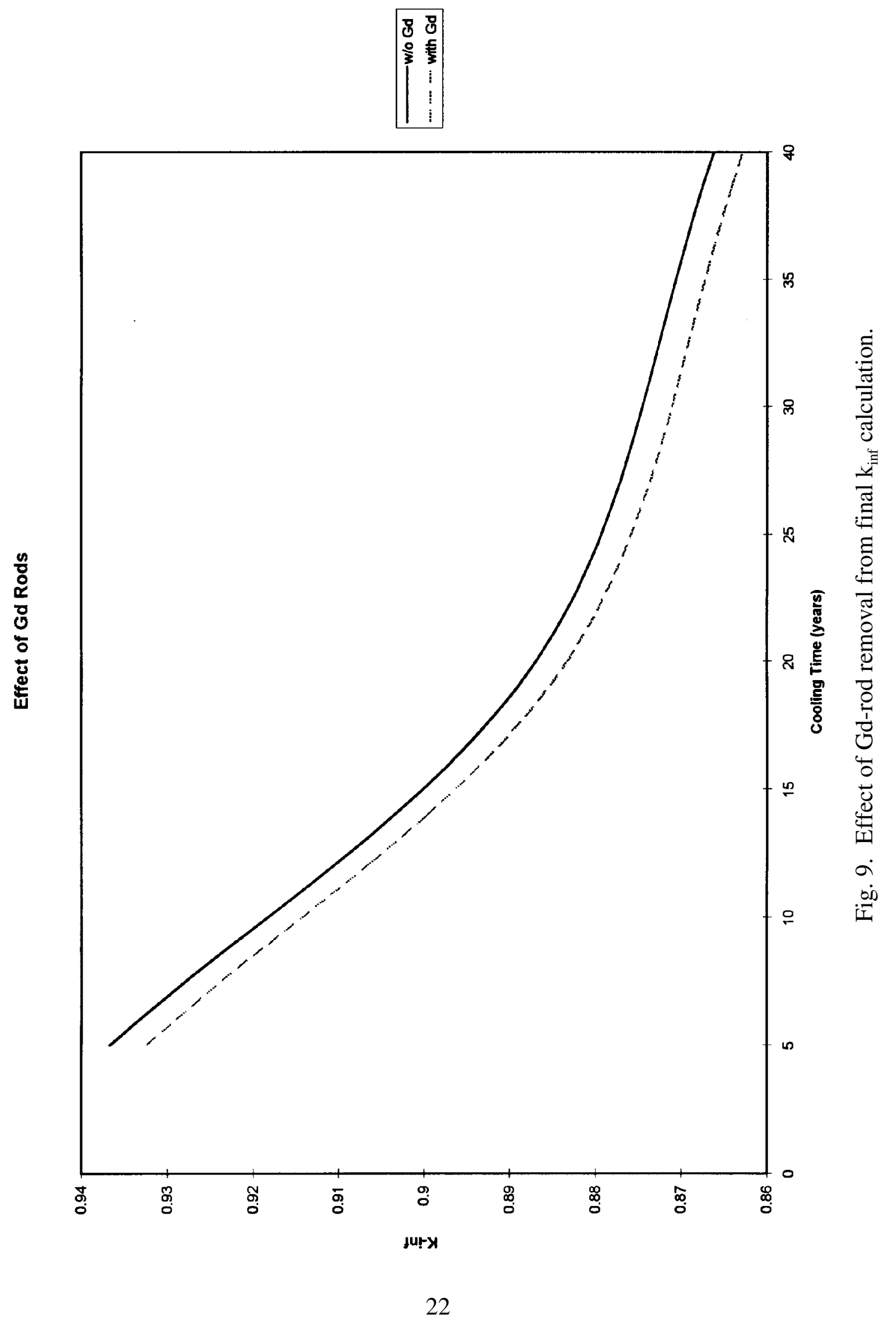




\section{RANKING RESULTS}

A final task in this work determined actinide and fission product absorption rankings and compared them with previous $17 \times 17$ PWR rankings 8 The absorption rankings in this work were determined for a $33 \mathrm{GWd} / \mathrm{t}, 3.1 \mathrm{wt} \%$ and 5-year-cooled BWR assembly. Tables 6 and 7 compare the current rankings with previous PWR rankings for actinides and fission products, respectively. The rankings are in general quite comparable with those of a PWR fuel assembly with only minor differences in rankings of 1 to 2 places. The only major difference is in the fission products ${ }^{155} \mathrm{Gd}$ and ${ }^{157} \mathrm{Gd}$. These differences are quite understandable, considering the presence of $\mathrm{Gd}$ rods in a BWR model. The relatively large amount of these isotopes present in the $\mathrm{Gd}$ rods makes the additional amount built up due to fission much less important. Tables 6 and 7 give isotopic rankings for BWR assemblies that correspond to two different axial locations, near the top (low water density) and near the bottom (high water density) of the fuel assembly. These rankings are essentially identical, indicating that no differences exist in the importance of isotopes over the axial range of the assembly.

Upon further investigation of the differences in rankings for the top 3-4 isotopes shown in Tables 6 and 7, it was noted that these rankings are sensitive to a number of parameters, including burnup, enrichment, and the assembly-to-assembly spacing in the reactor. The rankings for a second PWR assembly type were determined for comparison. The rankings for a $14 \times 14 \mathrm{PWR}$ are very similar to those of the BWR cases, with the burnups and enrichments being very much the same for all cases. The key parameter appears to be the assembly-to-assembly spacings which are quite different between the two PWR cases. The ranking changes are spectral related in that the assembly with the hardest spectrum is the $17 \times 17 \mathrm{PWR}$, and, hence, has the highest ${ }^{239} \mathrm{Pu}$ ranking. 
Table 6. Comparison of $\mathrm{PWR}^{a}$ and $\mathrm{BWR}^{b}$ absorption rankings for actinides

\begin{tabular}{lcccc}
\hline $\mathrm{Case}$ & $\begin{array}{c}\text { BWR (top) } \\
\text { absorption fraction } \\
\text { rank }\end{array}$ & $\begin{array}{c}\text { BWR (bottom) } \\
\text { absorption fraction } \\
\text { rank }\end{array}$ & $\begin{array}{c}17 \times 17 \mathrm{PWR}^{a} \\
\text { absorption fraction } \\
\text { rank }\end{array}$ & $\begin{array}{c}14 \times 14 \mathrm{PWR}^{c} \\
\text { absorption fraction } \\
\text { rank }\end{array}$ \\
\hline${ }^{239} \mathrm{Pu}$ & 2 & 2 & 1 & 2 \\
${ }^{238} \mathrm{U}$ & 1 & 1 & 2 & 1 \\
${ }^{235} \mathrm{U}$ & 3 & 4 & 3 & 4 \\
${ }^{240} \mathrm{Pu}$ & 4 & 3 & 4 & 3 \\
${ }^{241} \mathrm{Pu}$ & 5 & 5 & 5 & 5 \\
${ }^{241} \mathrm{Am}$ & 7 & 7 & 6 & 6 \\
${ }^{237} \mathrm{~Np}$ & 9 & 9 & 8 & 9 \\
${ }^{236} \mathrm{U}$ & 6 & 6 & 7 & 7 \\
${ }^{242} \mathrm{Pu}$ & 8 & 8 & 9 & 11 \\
${ }^{243} \mathrm{Am}$ & 10 & 11 & 10 & 12 \\
${ }^{234} \mathrm{U}$ & 12 & 12 & 11 & 10 \\
${ }^{238} \mathrm{Pu}$ & 11 & 10 & NA & 13 \\
${ }^{242 \mathrm{~m}} \mathrm{~A}$ & 13 & 13 & NA & 8 \\
\hline
\end{tabular}

${ }^{a}$ Corresponds to $17 \times 17 \mathrm{PWR}, 3 \%$ enrichment, $35-\mathrm{GWd} / \mathrm{t}$ with 5-year cooling time. These values were taken from ref. 8 .

${ }^{b}$ Corresponds to $8 \times 8$ BWR, $3.1 \%$ enrichment, 33-GWd/t with 5-year cooling time. ${ }^{c}$ Corresponds to $14 \times 14$ PWR, 3\% enrichment, 33-GWd/t with 5-year cooling time.

${ }^{d}$ Not available. 
Table 7. Comparison of $\mathrm{PWR}^{a}$ and $\mathrm{BWR}^{b}$ absorption rankings for fission products

\begin{tabular}{|c|c|c|c|c|c|}
\hline Case & $\begin{array}{c}\text { PWR } \\
\Delta \mathrm{k} \\
\text { rank }\end{array}$ & $\begin{array}{c}\mathrm{PWR}^{a} \\
\text { absorption } \\
\text { fraction rank }\end{array}$ & $\begin{array}{c}\mathrm{PWR}^{c} \\
\text { absorption } \\
\text { fraction rank }\end{array}$ & $\begin{array}{l}\text { BWR (top) } \\
\text { absorption } \\
\text { fraction rank }\end{array}$ & $\begin{array}{c}\text { BWR (bottom) } \\
\text { absorption } \\
\text { fraction rank }\end{array}$ \\
\hline${ }^{149} \mathrm{Sm}$ & 1 & 1 & 3 & 3 & 3 \\
\hline${ }^{143} \mathrm{Nd}$ & 2 & 2 & 2 & 2 & 2 \\
\hline${ }^{103} \mathrm{Rh}$ & 3 & 3 & 1 & 1 & 1 \\
\hline${ }^{151} \mathrm{Sm}$ & 4 & 4 & 9 & 8 & 8 \\
\hline${ }^{155} \mathrm{Gd}$ & 5 & 6 & 4 & 17 & 15 \\
\hline${ }^{131} \mathrm{Xe}$ & 6 & 5 & 5 & 5 & 5 \\
\hline${ }^{133} \mathrm{Cs}$ & 7 & 7 & 6 & 4 & 4 \\
\hline${ }^{99} \mathrm{Tc}$ & 8 & 8 & 7 & 6 & 6 \\
\hline${ }^{152} \mathrm{Sm}$ & 9 & 9 & 8 & 7 & 7 \\
\hline${ }^{153} \mathrm{Eu}$ & 10 & 10 & 10 & 9 & 9 \\
\hline${ }^{145} \mathrm{Nd}$ & 11 & 11 & 11 & 10 & 10 \\
\hline${ }^{150} \mathrm{Sm}$ & 12 & 12 & 15 & 14 & 13 \\
\hline${ }^{147} \mathrm{Sm}$ & 13 & 13 & 12 & 11 & 11 \\
\hline${ }^{109} \mathrm{Ag}$ & 14 & 14 & 14 & 13 & 14 \\
\hline${ }^{95} \mathrm{Mo}$ & 15 & 15 & 13 & 12 & 12 \\
\hline${ }^{101} \mathrm{Ru}$ & 16 & 16 & 17 & 15 & 17 \\
\hline${ }^{157} \mathrm{Gd}$ & 17 & 18 & 28 & 46 & 44 \\
\hline${ }^{105} \mathrm{Pd}$ & 18 & 17 & 20 & 19 & 20 \\
\hline${ }^{141} \mathrm{Pr}$ & 19 & 19 & 21 & 21 & 21 \\
\hline${ }^{147} \mathrm{Pm}$ & $\mathrm{NA}^{c}$ & NA & 18 & 16 & 16 \\
\hline${ }^{154} \mathrm{Eu}$ & NA & NA & 16 & 18 & 18 \\
\hline${ }^{155} \mathrm{Eu}$ & NA & NA & 19 & 20 & 19 \\
\hline
\end{tabular}

${ }^{a}$ Corresponds to $17 \times 17 \mathrm{PWR}, 3 \%$ enrichment, $35 \mathrm{GWd} / \mathrm{t}$ with 5-year cooling time. These values were taken from ref. 8 .

${ }^{b}$ Corresponds to $8 \times 8 \mathrm{BWR}, 3.1 \%$ enrichment, $33 \mathrm{GWd} / \mathrm{t}$ with 5-year cooling time. ${ }^{c}$ Corresponds to $14 \times 14 \mathrm{PWR}, 3 \%$ enrichment, $33 \mathrm{Gwd} / \mathrm{t}$ with 5-year cooling time. ${ }^{d}$ Not available. 


\section{REFERENCES}

1. O. W. Hermann and C. V. Parks, "SAS2H: A Coupled One-Dimensional Depletion and Shielding Analysis Module," Sect. S2 in SCALE: A Modular Code System for Performing Standardized Computer Analyses for Licensing Evaluations, NUREG/CR-0200, Rev. 5 (ORNL/NUREG/CSD-2/R5), Vols, I, II, and III (March 1997). Available from Radiation Shielding Information and Computational Center as CCC-545.

2. L. M. Petrie and N. F. Landers, "KENO V.a: An Improved Monte Carlo Criticality Program with Supergrouping," Sect. F11 of SCALE: A Modular Code System for Performing Standardized Computer Analyses for Licensing Evaluations, NUREG/CR-0200, Rev. 5 (ORNL/NUREG/CSD-2/R5), Vols, I, II, and III (March 1997). Available from Radiation Shielding Information and Computational Center as CCC-545.

3. Personal correspondence from David Henderson, Framatome Cogema Fuels, to Bryan Broadhead, ORNL, June 18, 1997.

4. Personal correspondence from David Henderson, Framatome Cogema Fuels, to Bryan Broadhead, ORNL, July 23, 1997.

5. James H. Rust, Nuclear Power Plant Engineering, Haralson Publishing Company, Buchanan, Ga., 1979.

6. O. W. Hermann, C. V. Parks, J. P. Renier, J. W. Roddy, R. C. Ashline, W. B. Wilson, and R. J. LaBauve, Multicode Comparison of Selected Source Term Computer Codes, ORNL/CSD/TM-251, Oak Ridge National Laboratory, Oak Ridge, Tenn., April 1989.

7. M. D. DeHart, Sensitivity and Parametric Evaluations of Significant Aspects of Burnup Credit for PWR Spent Fuel Packages, ORNL/TM-12973, Oak Ridge National Laboratory, Oak Ridge, Tenn., May 1996.

8. B. L. Broadhead, M. D. DeHart, J. C. Ryman, J. S. Tang, and C. V. Parks, Investigation of Nuclide Importance to Functional Requirements Related to Transport and Long-Term Storage of LWR Spent Fuel, ORNL/TM-12742, Oak Ridge National Laboratory, Oak Ridge, Tenn., June 1995. 


\section{INTERNAL DISTRIBUTION}

1. S. M. Bowman

2-6. B. L. Broadhead

7. W. C. Carter

8-12. M. D. DeHart

13. M. B. Emmett

14. W. E. Ford III

15. O. W. Hermann

16. C. M. Hopper

17. M. A. Kuliasha
18. B. D. Murphy

19-23. C. V. Parks

24. L. M. Petrie

25. C. H. Shappert

26. R. M. Westfall

27. Central Research Library

28-29. Laboratory Records Department (for submission to OSTI)

30. Laboratory Records, ORNL (RC)

\section{EXTERNAL DISTRIBUTION}

31. T. W. Doering, Framatome Cogema Fuels, 1180 Town Center Drive, Las Vegas, NV 89134

32. P. Gottlieb, Framatome Cogema Fuels, 1180 Town Center Drive, Las Vegas, NV 89134

33. D. Henderson, Framatome Cogema Fuels, 1180 Town Center Drive, Las Vegas, NV 89134

34. D. A. Thomas, Framatome Cogema Fuels, 1180 Town Center Drive, Las Vegas, NV 89134 